\title{
Constructing Religious Moderation in Islamic Higher Education
}

\author{
Abdul Haris Abdullah \& Shinta Nento \\ IAIN Sultan Amai Gorontalo, IAIN Manado
}

\begin{abstract}
This study focuses on students' perceptions to explore and measure the elements that form religious moderation. Nine common factors are understood: understanding Islam, sharia balance, values of human beings, plurality in religion, rights of minority groups, national engagement, anti-violence, an attitude of friendship, and educational curricula. The nine factors seem to be interlinked too intimately, and therefore a theme is needed to simplify and make them more operable. This research method is quantitative with the type of explantation research and using a survey approach. The study involved 90 samples. Data analysis techniques of these factors used the help of computer programs such as SPSS software. The results demonstrated that these nine factors could be reduced to produce new names for the three main factors, namely, diversity, peace, and education. The three designations of these factors will help facilitate the approach in an effort to create an understanding of moderation among students in Islamic religious colleges.
\end{abstract}

Keywords: Factor analysis, religious moderation

\section{Pembentukan Moderasi Keagamaan di Perguruan Tinggi Islam}

\begin{abstract}
Abstrak
Penelitian ini berfokus pada persepsi siswa untuk menggali dan mengukur elemen-elemen yang membentuk moderasi beragama. Ada sembilan faktor umum yang dipahami: pemahaman Islam, keseimbangan syariah, nilai-nilai kemanusiaan, pluralitas dalam agama, hak-hak kelompok minoritas, keterlibatan nasional, anti kekerasan, sikap persahabatan dan kurikulum pendidikan. Kesembilan faktor tampaknya saling terkait terlalu erat, dan oleh karena itu diperlukan sebuah tema untuk menyederhanakan dan membuatnya lebih dapat dioperasikan. Metode penelitian ini adalah kuantitatif dengan jenis penelitian eksplanasi dan menggunakan pendekatan survey. Penelitian ini melibatkan 90 sampel. Teknik analisis data faktor-faktor tersebut menggunakan bantuan program komputer seperti software SPSS. Hasil penelitian menunjukkan bahwa kesembilan faktor tersebut dapat direduksi untuk menghasilkan nama baru bagi tiga faktor utama, yaitu keragaman, perdamaian dan pendidikan. Ketiga sebutan faktor tersebut akan membantu mempermudah pendekatan dalam upaya menciptakan pemahaman moderasi di kalangan mahasiswa di Perguruan Tinggi Agama Islam (PTAI).
\end{abstract}

Kata Kunci: Moderasi beragama, islam, perguruan tinggi

Author correspondence

Email: abdulharisabdullah1976@iaingorontalo.ac.id

Available online at http://journal.iaingorontalo.ac.id/index.php/au/index 


\section{A. Introduction}

Following the reformation era, Indonesia experinced any issues in nationaly, as well as freedom of expression, speech, and association. Because freedom is the most important feature of a democracy, whether you like it or not, the state, society, and government must accept it as a consequence of democracy itself. This freedom is what allows the entire community to be more active and creative in interpreting that freedom under their own desires. The impact of this freedom also has an impact on a person's perspective on religion, particularly in the context of higher education. People appear to have the authority to carry out any religious order. However, this freedom must not exceed the limit, because other people have the same rights in carrying out their respective religious orders.

Here is where the option of the path of righteousness among people is examined. This test procedure is measured by the questions: Does not your religious interpretation hinder the exercise of their rights? Is the problem of other people's rights part of the correct religious way? There are several options for responding to these questions, depending on the viewpoint the response is given.

From the state's point of view, it may argue that, in the eyes of the law, all actions of society are legitimate as long as they do not interfere with the public order legally recognized and its derivatives ${ }^{1}$. State in its preference of actions against communal groups which threaten the right and always wrong public order and civil rights ${ }^{2}$. In the name of public interest, the strength of the state is becoming greater as it stands. Consequently, the understanding of some religions in the association of society is not allowed by the state if it hinders others' rights. The state does not tolerate adherents of religious beliefs that make understanding a threat to others' rights ${ }^{3}$.

\footnotetext{
${ }^{1}$ Falentino Y Salea, "Tindak Pidana Mengganggu Ketenangan Sebagai Tindak Pidana Terhadap Ketertiban Umum Dalam Pasal 172 Dan Pasal 503 KUHP," Lex Crimen 9, no. 4 (2020).

${ }_{2}^{2}$ Jeffrey M Berry, Lobbying for the People: The Political Behavior of Public Interest Groups (Princeton University Press, 2015).

3 Tazul Islam and Amina Khatun, "Islamic Moderation' in Perspectives: A Comparison Between Oriental And Occidental Scholarships," International Journal of Nusantara Islam 3, no. 2 (2015): 69, https://doi.org/10.15575/ijni.v3i2.488.
} 
Additionally, judging from the point of view of religious scholars, they claim that the interpretation and passion of faith that they teach the world is a decision to be righteous before God and man $^{4}$. Since this religion's values and teachings are the pillars of justice in God and man ${ }^{5}$, they want others to become more interested through their understanding and faith in the struggle in turn. Efforts to spread knowledge and belief definitely have significant obstacles since practically every human being has limited teachings and beliefs, while no human being living today has any inherent teachings or beliefs. From both the state's point of view and the point of view of understanding the teachings of religion, it seems like these two points of view are face-to-face.

Conflicts among religious people are typically affected by exclusive religious attitudes and battles among communities to obtain support by ignoring tolerant attitudes $^{6}$. Efforts to prevent religious disharmony ought to be cultivated in a moderate way, namely inclusive or open attitudes as followers of religions that are not excessive or irrational attitudes in response to diversity differences. Moderate derived from the absorption of the word al-wasath means best and great (QS. AlBaqarah, 2:143), and it is said in the hadith that the best issue is the one in the middle $^{7}$. Moderate Islam provides a consensus solution and is at the core of addressing differences. Moderate Islam encourages an attitude of tolerance, reverence and confidence in each other's reality. Moderation is also a representation of Indonesia's culture as a pearl of local wisdom ${ }^{8}$.

On the other hand, there are several varieties of counter-productive exchanges of ties between each believer. Through many journals dealing with human relationships, some of the following topics are the driving force behind ties

\footnotetext{
4 Ahmad Saifuddin, Psikologi Agama: Implementasi Psikologi Untuk Memahami Perilaku Agama (Kencana, 2019).

5 Azyumardi Azra, “Kesalehan Dan Politik: Islam Indonesia,” Studia Islamika 25, no. 3 (2018): 63950.

6 Muhamad Murtadlo, "Menakar Moderasi Beragama Di Perguruan Tinggi," Badan Litbang Dan Diklat Kementerian Agama RI, 2019, https://balitbangdiklat.kemenag.go.id/berita/menakarmoderasi-beragama-di-perguruan-tinggi.

7 Agus Akhmadi, "Moderasi Beragama Dalam Keragaman Indonesia Religious Moderation in Indonesia ' S Diversity," Jurnal Diklat Keagamaan 13, no. 2 (2008): 45-55.

${ }^{8}$ Ali Nurdin, "Model Moderasi Beragama Berbasis Pesantren Salaf," Islamica Jurnal Studi Keislaman 14, no. 1 (2019): 1-21, https://doi.org/https://doi.org/10.15642/islamica.2019.14.1.82-102.
} 
and violence, namely: -doctrinal differences ${ }^{9}$; -mental attitudes ${ }^{10}$; -ethnicity and race differences ${ }^{11}$; -majority ${ }^{12}$; -minority ${ }^{13}$; -syncretism ${ }^{14}$; -social prejudice ${ }^{15}$; fanaticism ${ }^{16}$;-miscommunication ${ }^{17}$;-social and political interests mixing18; -do not understand religious teachings ${ }^{19}$; - socio-economic problems ${ }^{20}$; - pragmatism $^{21}$; hedonism $^{22}$; doctrine ${ }^{23}$; freedom association ${ }^{24}$;- freedom of speech $^{25}$; -freedom of expression ${ }^{26}$.

9 Susilo Wibisono, Winnifred R. Louis, and Jolanda Jetten, "A Multidimensional Analysis of Religious
Extremism," Frontiers in Psychology 10, no. November (2019), https://doi.org/10.3389/fpsyg.2019.02560.

10 Katharine S. Adams et al., "Relationship of Christian Beliefs to Attitudes toward People with Mental Illness," American Journal of Psychotherapy 71, no. 3 (2018): 104-9, https://doi.org/10.1176/appi.psychotherapy.20180022.

${ }^{11}$ Karen Connelly, "Undermining Cosmopolitanism - Cyber-Racism Narratives in Australia," Sites: A Journal of Social Anthropology and Cultural Studies 13, no. 1 (2016): 156, https://doi.org/10.11157/sites-vol13iss1id318.

12 Itesh Sachdev and Richard Y. Bourhis, "Power and Status Differentials in Minority and Majority Group Relations," European Journal of Social Psychology 21, no. 1 (1991): 1-24, https://doi.org/10.1002/ejsp.2420210102.

13 Aarati Kasturirangan, Sandhya Krishnan, and Stephanie Riger, "The Impact of Culture and Minority Status on Women's Experience of Domestic Violence," Trauma, Violence, \& Abuse 5, no. 4 (2004): 318-32, https://doi.org/10.1177/1524838004269487.

14 Ashadi, "Sinkretisme Dalam Arsitektur: Metodologi," Jurnal Arsitektur NALARs Vol.13 No., no. 8 Maret 2017 (2014): 23-30.

${ }^{15}$ Sachdev and Bourhis, "Power and Status Differentials in Minority and Majority Group Relations."

16 David Brown and Ian Douglas Wilson, "Ethnicized Violence in Indonesia: Where Criminals and Fanatics Meet," Nationalism and Ethnic Politics 13, no. 3 (August 16, 2007): 367-403, https://doi.org/10.1080/13537110701451579.

17 Ayșe Gözde Koyuncu and Rufaro Denise Chipindu, "How Cultural Differences Influence Conflict Within an Organization: A Case Study of Near East University," International Journal of Organizational Leadership 8, no. 1 (2020): 112-28, https://doi.org/10.33844/ijol.2020.60478.

${ }_{18}$ Christopher G Ellison and Marc A Musick, "Southern Intolerance: A Fundamentalist Effect?*," Social Forces 72, no. 2 (December 1, 1993): 379-98, https://doi.org/10.1093/sf/72.2.379.

${ }_{19}$ David Lukoff, Francis G Lu, and Robert Turner, "Cultural Considerations in the Assessment and Treatment of Religious and Spiritual Problems," Psychiatric Clinics of North America 18, no. 3 (1995): 467-85, https://doi.org/https://doi.org/10.1016/S0193-953X(18)30035-2.

${ }^{20}$ Gudrun østby, "Polarization, Horizontal Inequalities and Violent Civil Conflict," Journal of Peace Research - J PEACE RES 45 (March 1, 2008): 143-62, https://doi.org/10.1177/0022343307087169.

${ }^{21}$ Mustafa Emirbayer and Chad Alan Goldberg, "Pragmatism, Bourdieu, and Collective Emotions in Contentious Politics," Theory and Society 34, no. 5 (2005): 469-518, https://doi.org/10.1007/s11186-005-1619-x.

22 Suresh Ramanathan and Geetha Menon, "Time-Varying Effects of Chronic Hedonic Goals on Impulsive Behavior," Journal of Marketing Research 43 (September 1, 2006), https://doi.org/10.2139/ssrn.778944.

${ }^{23}$ Ellison and Musick, "Southern Intolerance: A Fundamentalist Effect?*."

${ }^{24}$ Mark Harcourt et al., "Boosting Union Membership: Reconciling Liberal and Social Democratic Conceptions of Freedom of Association via a Union Default," Industrial Law Journal, September 10, 2020, https://doi.org/10.1093/indlaw/dwaa018.

${ }^{25}$ Ramanathan and Menon, "Time-Varying Effects of Chronic Hedonic Goals on Impulsive Behavior." ${ }^{26}$ Ricardo Echavarria, "Democratic Freedom of Expression," Open Journal of Philosophy 03 (January 1, 2013): 380-90, https://doi.org/10.4236/ojpp.2013.33058. 
One of the scholars who elaborated a lot about moderation was Yusuf alQaradhawi. He discovered that these signs of moderation include: (1) a holistic interpretation of Islam; (2) a compromise between the Shari'ah and the modern trends; (3) endorse for peace and respect for human values; (4) acceptance of religious, cultural and political plurality; and (5) recognition of minority rights ${ }^{27}$.

According to the Book of Religious Moderation published by the Ministry of Religious Affairs, there are four religious moderation indicators: 1) national commitment; 2) tolerance; 3) anti-violence; and 4) accommodating local culture. These four indicators can recognize how strongly a person in Indonesia practises religious moderation and how much vulnerability they have. These vulnerabilities are recognized so that we can recognize and take appropriate steps to strengthen religious moderation ${ }^{28}$.

According to the author, a protracted and tiring conceptual argument will catch many statements of aspects like in the final two subparagraphs, which seek to establish a mild knowledge of religion. Therefore, the naming of factors must be simplified in allowing them to be operational and cover various aspects.

Based on efforts to address these concerns, this article aims to examine and measure the variety of factors forming religious moderation in students' perceptions in order to develop a simpler term for forming factors of religious moderation, with the hope that stakeholders would then receive a classified, concise, and simple picture to guide them solve the social issues arising in an inappropriate religious perspective.

\section{B. Muslim Moderat vs Extrimisme Muslim}

A qualitative study provides an analysis equating Muslim extremism with violence that Muslims or any religious group may be extreme in some dimensions but moderate in other dimensions, for instance, extremes in rituals and moderates in politics. It is further said that religious extremists differ in several dimensions and express religion and put the group's goals first. By using Indonesian Muslim

\footnotetext{
27 Edy Sutrisno, "Aktualisasi Moderasi Beragama Di Lembaga Pendidikan," Jurnal Bimas Islam 12, no. 2 (2019): 323-48, https://doi.org/10.37302/jbi.v12i2.113.

${ }^{28}$ Tim Penyusun, Moderasi Beragama, Kementerian Agama, vol. 53, 2013.
} 
groups' context to explore these ideas, it is proposed that religiosity in Muslims can be moderate in one dimension and radical/extreme in another dimension. Labelling a group or individual as extremist is often misleading. The label has a degrading meaning and too often links extremism to terrorism. Failure to understand religious extremism complexities risks stigmatizing some religious groups as irrational and supporting violence. These negative stereotypes can lead to segregation, loss of status, discrimination, wasted resources in misguided counter-terrorism initiatives, and waste of political capital. Understanding religious multidimensional in the context of religious extremism will help in accurately describing this phenomenon ${ }^{29}$. In religion, extreme behaviour gives rise to claims of absolute truth that address a radical mindset in turn, even attempting to negate the numerous views of rigorously studied dogma ${ }^{30}$.

In deradicalization, religious moderation is essential, namely; 1). Provide awareness of human nature, without cultural, religious and national obstacles, to do useful. 2). Moderate attitudes cultivate hospitality and kindness, maintain humanity's integrity, and enjoy a life based on religion, morality and universal ethics. 3). Religious people are citizens and become part of the people of the world at the same time. 4). Religious moderation is a burden of principles and traditions focused on the value of Pancasila to avoid radicalism and maintain peace on the Indonesian planet. 5). Religious moderation should accommodate multicultural and pluralistic societies. (6). In order to establish unity within the same religion among different traditions, religious modesty becomes essential ${ }^{31}$.

Religion requires egalitarian relations to respect equality, degrees and, at the same time, uphold the dignity of humanity ${ }^{32}$. Religion is moderate, and there is no extreme religion left. God sent down religion through a prophet or a saint to create al-'is (justice) as a middle and sustainable way. Religious scripture as a religious reference is well understood and correct to become mercy for all nature.

\footnotetext{
29 Wibisono, Louis, and Jetten, "A Multidimensional Analysis of Religious Extremism."

${ }^{30}$ Nur Alim et al., "Singularitas Agama: Identifikasi Aliran Dan Paham Radikal Di Kendari," Al-Ulum 18, no. 2 (2018): 271-300, https://doi.org/10.30603/au.v18i2.487.

${ }^{31}$ Arifinsyah, "The Urgency of Religious Moderation in Preventing Radicalism in Indonesia," Esensia 21, no. 1 (2020): 91-108, https://doi.org/https://doi.org/10.14421/esensia.v21i1.2199.

32 Pratisto Tinarso, Supartiningsih Supartiningsih, and Hardono Hadi, "Aksiologi Nilai Egaliter Budaya 'Arek Suroboyo'.," Al-Ulum 18, no. 2 (2018): 395-416, https://doi.org/10.30603/au.v18i2.554.
} 
The scriptures are not loaded with translators' interests and desires, nor does it close the possibility of extreme attitudes ${ }^{33}$. Besides, this interpretation is made in a literal or literary way that gives birth to a rigid understanding and leads to justification. For example, all laws must be following God's law, whereas the law or law prescribed by man is misguided.

For the sake of national unity and state sovereignty, the regulation of diversity and preservation of religious peace is significant as the capital of the nation ${ }^{34}$. Management and protection can be done with guidance and education based on religious moderation. Coaching and religious moderation are included in the curriculum informal educational institutions, ranging from secondary education to high levels ${ }^{35}$. So, a vision of understanding and the role of religious moderation will be carried out in preventing radicalism and building peace in Indonesia and the world. Religious moderation is the most appropriate value and practice to realize the benefits of this earth. A moderate, fair, balanced mental attitude and strengthening local wisdom values are critical to its management. Indonesia's diversity is familiar to Muslims, even its original character, because Islam is older and is inherent in prophetic missions. As a majority in Indonesia, Muslims not only accept moderation but also encourage their followers to adopt it as a way of life. Moderate religion becomes important for constructive relations between external religions and necessary internally to create harmony between different traditions in one religion. Internal conflicts in religion are no lighter than external conflicts ${ }^{36}$.

A qualitative-quantitative descriptive study shows that understanding, response, and religion. Indicators on every aspect are higher than not moderate or extreme indicators. In terms of knowledge, students do not understand the tag line "Moderation of religion", and the provision of religious moderation material in and

\footnotetext{
${ }^{33}$ André Lefevere, Translation, Rewriting, and the Manipulation of Literary Fame (Taylor \& Francis, 2016).

${ }^{34}$ Steven Vertovec, "Super-Diversity and Its Implications," Ethnic and Racial Studies 30, no. 6 (2007): 1024-54.

${ }^{35}$ Che Noraini Hashim and Hasan Langgulung, "Islamic Religious Curriculum in Muslim Countries: The Experiences of Indonesia and Malaysia," Bulletin of Education \& Research 30, no. 1 (2008): 119.

${ }^{36}$ Arifinsyah, "The Urgency of Religious Moderation in Preventing Radicalism in Indonesia."
} 
socialization or scientific discussion forums are still limited. In terms of behaviour, students show tolerance, national commitment, resist violence, and accommodate local culture. In the aspect of religious methods, students who are moderate in dealing with religious issues are prioritized to uphold the values of character and Islamic identity rahmatan lil alamin rather than using violence in problem-solving. Facing an era of disruption, most students can sift through the information obtained and know how to process the information they receive wisely and responsibly, confirm and consider the truth first, and try to know the benefits of information before sharing it ${ }^{37}$.

Islamic moderation has received a lot of academic and media attention both in the West and in the East. However, the tagging of the term itself is still very paradoxical because different regions and contexts give different meanings. In western societies, moderate Islam deals with liberal social norms, hermeneutics, political pluralism, democratic processes, organizational proximity, and the view of state legitimacy over violent monopolies, willingness to cooperate or compromise. Muslim scholars first explored the lexical meaning of his Arabic substitute, "wasatiyyah". Second, they explored the textual meaning of the word "wasatiyyah" used in orthodox texts, namely the Koran and the tradition (Sunnah) of the Prophet Muhammad (saw). According to them, moderation is the best fit, a balanced or middle position between two extremes, namely extremism and weakness. Its use of the term contextualized in terms of counter-extremism, simple socio-religious behaviour. The study found considerable textual and contextual differences in the term 'Islamic moderation' between East and West. Further moderation takes on a different meaning pattern when it implies various mechanisms such as inclusion, participation, organizational interests, party autonomy, social learning, and socioeconomic. The moderation requires can be expected to vary cross-country and overtime because moderation requires adjustment to different contexts. However, from the western perspective, 'moderation' is not a category but a process. A process, like democracy, in which

\footnotetext{
37 Nuraliah Ali, "Measuring Religious Moderation Among Muslim Students at Public Colleges in Kalimantan Facing Disruption Era," INFERENSI: Jurnal Penelitian Sosial Keagamaan 14, no. 1 (2020): 1-24, https://doi.org/10.18326/infsl3.v14i1.1-24.
} 
radical groups are allowed to function within the domain of democracy. As a result, they abandoned their revolutionary mottos and radical programs. They often move from anti-western to pro-western. ${ }^{38}$

Then another article attempts to present a brief overview of Islamic religious sources and discuss whether the statement that Islam is not moderate is true or false, particularly concerning moderation methods used in religious teachings, criteria and interfaith relations, as well as to prove that it is a religion. Flexibility, compassion, comfort, moderation, and not extremism. The study uses the analysis of the contents of the related verses in the Scriptures and the Prophet's words, which relate to the moderation process and explain the chosen Interpreter of the Quran. It takes into account the idea of moderation and describing important terms (1) excess or extremism, (2) incompetence, negligence or abuse, and (3) a straight path that leads to an understanding of the proper sense of moderation. Explore its most critical attributes, such as (1) perfection or goodness, (2) justice, (3) ease and removal of difficulties, (4) wisdom, (5) correctness $^{39}$.

The study employed a qualitative approach to interpreting religious values with a phenomenological approach. The religious moderation in Islamic higher education promotes normative philosophical principles in interpreting religious moderation founded on divine consciousness. It is natural that their behaviour and acts also reflect religious and moral beliefs. Therefore, every dimension of their lives is inseparable from the Qur'an ethics, including religious values, attitudes and behaviour. This is what researchers call theological moderation ${ }^{40}$. Islam as a social practice should be explained as a barometer in promoting peaceful efforts in all respects while at the same time combating efforts to transform religion into a

\footnotetext{
38 Tazul Islam and Amina Khatun, “'Islamic Moderation' in Perspectives: A Comparison Between Oriental And Occidental Scholarships," International Journal of Nusantara Islam 3, no. 2 (2015): 69, https://doi.org/10.15575/ijni.v3i2.488.

39 Thameem Ushama, "Is Islam a Religion of Moderation or Extremism? A Study of Key Islamic Teachings," Asian Social Science 10, no. 8 (2014): 184-97, https://doi.org/10.5539/ass.v10n8p184. 40 Mustari Bosra, "Theological Moderation In The Islamic Boarding School (Pesantren): Phenomenological Prophetic Social Study In Pesantren In East Java," Akademika 25, no. 1 (2020): 118-38, https://doi.org/DOI: https://doi.org/10.32332/akademika.v25i1.2369.
} 
radical movement and intimidation that is becoming a negative stigma that continues to be sustained by the media throughout this time ${ }^{41}$.

A paper emphasizes the significance of God's conceptual portrayal in recognizing people's participation in their faith. More moderate versus more extreme types of faith, the author suggests moderate religious communities of a spiritual nature to reduce the excess of worldly affairs. This model is realistic. We need to explore the explanations for the moderate and extremist classification leading to a complete sense of where individuals with rather conservative religious views are correlated with the encouragement of violence ${ }^{42}$. As it could be acknowledged from an article that religious leaders need to be aware of articulating worldly affairs when dealing with social issues ${ }^{43}$. They can distinguish their personal views from religious views in the text as a universal dimension to not be caught up in hateful attitudes.

\section{Method and Result}

This research paradigm is quantitative with this type of explantation research. The approach uses survey methods. The research population is all students of the Islamic Education Management study program fourth semester. Faculty of Tarbiyah and Teacher Training of IAIN Sultan Amai Gorontalo.

Sample determination uses a ratio of 10:1, which means that ten samples are used with one variable. In this case, the researchers had nine free variables, so the sample was nine variables X $10=90$ samples. The data source comes from the primary data source collected via the instrument in the form of a questionnaire, which is distributed online using the google form to adjust the pandemic covid-19 by paying attention to the health protocols.

\footnotetext{
${ }^{41}$ Muhammad Khairil, "Wahdah Islamiyah's Counter-Radicalism Strategy Through The New Media Network in Da'wah Development Of Palu City," Al-Ulum 18, no. 2 (2018): 417-35, https://doi.org/10.30603/au.v18i2.610.

42 Wibisono, Louis, and Jetten, "A Multidimensional Analysis of Religious Extremism."

43 Moh Abdul et al., "Kontruksi Pemikiran Keagamaan Tentang Nilai-Nilai Nasionalisme Pada Penceramah Di Masjid Agung Surakarta Dan Sukoharjo IAIN Surakarta," Alulum Iain Gorontalo 18, no. 2 (2018): 481-500, https://doi.org/https://doi.org/10.30603/au.v18i2.660.
} 
Techniques for data processing used SPSS software. Study using a factor analysis approach through several technical phases of analysis ${ }^{44}$; the first, factor analysis calculates variables that are deemed conceivable to be used in the analysis. Besides, this test is performed by inserting all the current variables. These variables are subject to a variety of tests. The test's rationale is that if a variable has a propensity to a group and form a factor, it has a reasonably strong correlation with other variables. Conversely, variables with poor correlations with other variables appear not to be grouped within a given factor. The second stage is carried out the core process of factor analysis, namely the extraction of a set of variables that exist to form one or more factors.

Factors that are theoretically defined include nine factors, namely: a thorough understanding of Islam; understanding the balance of the Shariah and the changing times; reverence for the ideals of humanity; appreciation of diversity, religion, culture and politics; recognition of minority rights; national commitment; anti-violence; friendly, sympathy, respect for equality, morality and universality, improvement of the religious curriculum.

Whereas the descriptor for each factor is: to acknowledge that Islam is a religion that has teachings that rule several dimensions of human existence, such as social, political, economic, legal, moral, religious life; Understanding that Islam as a teaching of morality demands that the rule of law be reserved for the benefit of, for example, the production of zakat, infaq, sadaqoh, hajj, and relations with the environment; that Islam be part of efforts to preserve human benefit; that is, the values of righteousness in Islam as worship, where possible translated into relations with outside parties; That the life which Allah has created has a variety of choices according to the nature of a man who is free to obey lust or follow the guidance of the prophets; Realizing that minorities are the part that must have a secure, just, and respected life in their rights, as exemplified by the Prophet SAW; Know and understand that as part of the diverse nation's people, it is worth loving the nation where we live and engaging in the maintenance of the welfare of the nation; Recognizing that Islam is a teaching of peace or redemption, it is necessary

${ }^{44}$ Singgih Santoso, Statistik Multivariat (Elex Media Komputindo, 2010). 
to condemn all forms of violence as provided for in the civil laws which are regulated by the laws of the State; Behaviour is a mental attitude extracted from the outcomes of learning to promote a friendly attitude, display kindness, direct acts that maintain honesty, moral attitudes, and establish universal ethics in the community; education is an area of great values that are formally developed through school. That is why the curriculum taught must display and ensure its function of producing a godly generation and respecting others.

Analysis of measurement output looked at KMO (Kaiser-Meyer-Olkin measure) \& Barlett's. KMO \&Barlett's value of 0.704 above 0.50 and significance 0.000 is smaller than 0.05 ; then the sample variable can be analyzed further. KMO \&barlett's testing hypothesis is $\mathrm{HO}=$ the sample has not been adequately analyzed further; $\mathrm{Ha}=$ the sample has been adequately analyzed. The probability criteria by looking at a significant number more significant than $0.05=\mathrm{H} 0$ is accepted, whereas if the significance number is less than $0.05=\mathrm{H} 0$ is rejected. Thus, if this study $\mathrm{HO}$ is rejected, meaning the significance level is smaller than 0.05 , meaning testing can proceed to a next stage.

Then for anti-image matrices testing by paying attention to MSA numbers (Measure of Sampling Adequacy) ranging from 0 to 1 , criteria MSA $=1$ means variables can be predicted without errors; MSA greater than 0.50 can be done further tests; while MSA smaller than 0.50 variables are unpredictable. The test results showed that the overall MSA score in this study was above 0.50. Variables of a comprehensive understanding of Islam (0.564); a balance of shari'ah and the changing times (0.706); respect for human values (0.685); recognition of plurality, religion, culture, and politics (0.712); recognition of minority rights (0.724); national commitment (0.678); anti-violence friendly attitude, compassion, upholding dignity, morals and universal ethics 0.763); improvement of the religious curriculum (0.697). 


\begin{tabular}{ccc} 
Table 1. Total Variance Explained \\
\hline Component & \multicolumn{2}{c}{ Initial Eigenvalues } \\
\cline { 2 - 3 } Total & $\begin{array}{c}\text { \% of } \\
\text { Variance }\end{array}$ \\
\hline $\mathbf{1 .}$ & 3.710 & 41.223 \\
\hline $\mathbf{2 .}$ & 1.475 & 16.387 \\
\hline $\mathbf{3 .}$ & 1.097 & 12.188 \\
\hline $\mathbf{4 .}$ & .784 & 8.707 \\
\hline $\mathbf{5 .}$ & .706 & 7.842 \\
\hline $\mathbf{6 .}$ & .565 & 6.273 \\
\hline $\mathbf{7 .}$ & .294 & 3.272 \\
\hline $\mathbf{8 .}$ & .264 & 2.936 \\
\hline $\mathbf{9 .}$ & .106 & 1.172 \\
\hline
\end{tabular}

Table 1 explains that three factors are formed from 9 components after being extracted. The first-factor variant is $41.22 \%$, the second-factor variant is $16.38 \%$, and the third-factor variant is $12.18 \%$. If summed up the total of the three factors $(41.22 \%+16.38 \%+12.18 \%=69.78 \%$ can explain the original 9 variables

\section{Table 2. Component matrix}

\begin{tabular}{llccc}
\hline & \multicolumn{3}{c}{ Factors } & \multicolumn{3}{c}{ Component } \\
\cline { 3 - 5 } & & 1 & 2 & 3 \\
\hline 1 & $\begin{array}{l}\text { Comprehensive understanding } \\
\text { Islam }\end{array}$ & .354 & .706 & -.034 \\
\hline 2 & Sharia balance \& changing times & .553 & .401 & -.412 \\
\hline 3 & Respect for human values & .830 & -.328 & -.325 \\
\hline 4 & Recognition of religious plurality & .823 & -.278 & -.206 \\
\hline 5 & Recognition of minority rights & .772 & -.375 & .078 \\
\hline 6 & National commitment & .602 & -.346 & .524 \\
\hline 7 & Anti violence & .688 & .285 & -.228 \\
\hline 8 & Friendly attitude & .418 & .485 & .348 \\
\hline 9 & Improved religious curriculum & .553 & .232 & .570 \\
\hline
\end{tabular}

Table 2 shows the distribution of the nine variables on the three factors formed. The numbers in the table are loading factors, which indicate the magnitude of the correlation of factors with components. The process of determining which variable will go into factors 1,2 or 3 , namely by making an extensive correlation comparison on each row. Factor understanding Islam comprehensively entered in component 2 because the correlation value of factors with component 2 is greater than the correlation with components 1 and 3 . The 
balance factor of sharia understanding and the age of worship comes in component 2 because the correlation value is more significant than components 2 and 3 . The value respect factor of humanity comes in component 1 because the correlation value with factors 2 and 3 is small. The factor of recognising religious plurality comes in component 1 because the correlation value with components 2 and 3 is small. The minority rights recognition factor comes in component 1 because the correlation value with components 2 and 3 is smaller in value. The national commitment factor has a more significant correlation with component 1 than components 2 and 3.

Similarly, anti-hardness factors have a correlation factor with component 1 greater than components 2 and 3. The friendly attitude factor comes in component 2 because the correlation value with components 1 and 3 is smaller in value. Lastly, the religious curriculum's improvement factor is in factor 3 because the comparison of values with components 1 and 2 is small.

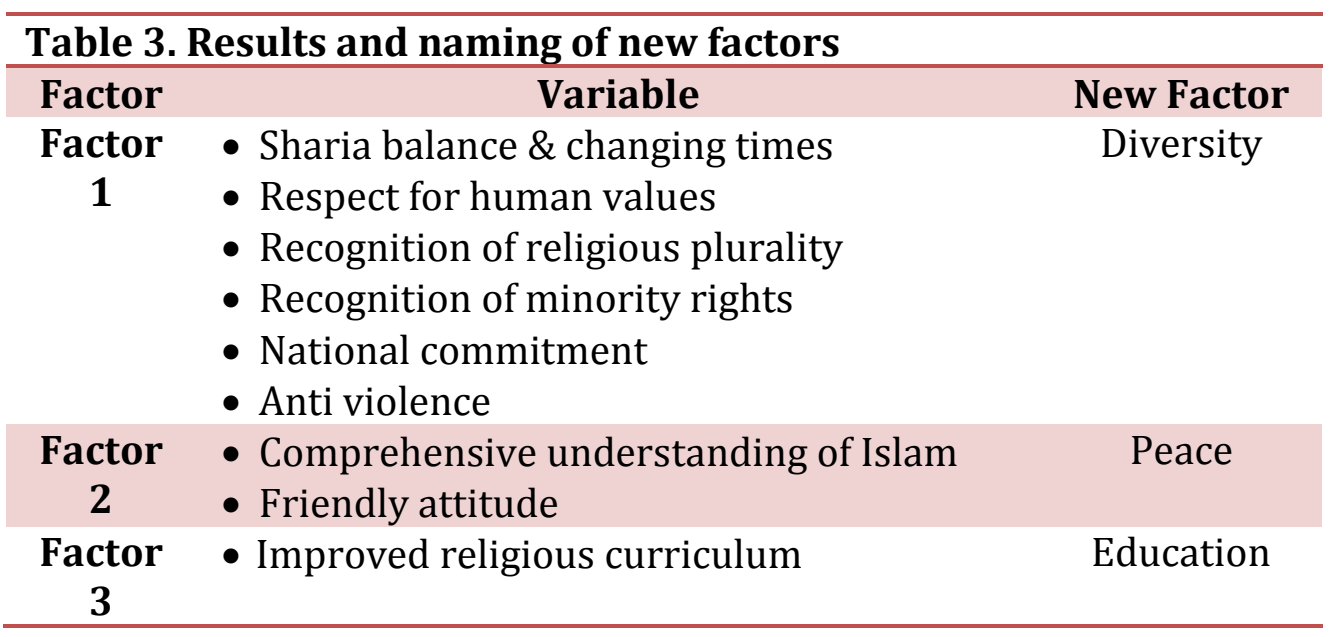

Table 3 shows the results and determination of new variable names after testing. Based on the analysis of the test results above, the nine variables studied by the factoring process can be reduced to three new factors: diversity, peace, and education.

The first factor with the new name of diversity consists of: balancing sharia understanding with the changing times; respect for human values; the recognition that plurality is natural; recognizing minority rights in togetherness; national 
commitment; and promoting anti-violence in community social relations. It can be understood from this factor that there is a group of students interpreting the importance of religious moderation by paying attention to diversity in public life.

The second factor with the new name of peace consists of a comprehensive understanding of Islamic teachings and shows the importance of a friendly attitude in an association. It can be understood from this factor that there is a group of students to behave moderately by prioritizing understanding Islam as comprehensive teaching and behaving kindly towards others in social relations.

The third factor with a new name is an education that improves the religious curriculum in the education unit. It can be understood from this factor that a group of students perceive efforts to understand moderate attitudes in religion, starting from education. This thing is a gradual planting of moderate religious attitudes to become part of everyone's personality.

\section{Discussion}

As a guide to life, Qur'an and Hadith teach goodness, harmony, and balance in the practices of human life in the world. None of these two critical texts teaches poor behaviour to humans. In reality, it comes from Islamic teachings. However, it was only the interpretation of a handful of people using the text as an excuse for their acts, for instance, an article reviewing the rulings of human rights courts and courts throughout France, banning the use of headscarves in public spaces ${ }^{45}$. In reality, such a forbidding stance will cause the antipasti of a group of people who feel oppressed by using symbols of their beliefs.

The teachings of religion, particularly Islam, without being encouraged to respect the value of humanity, are, in fact, among the core teachings of the main text, namely the Qur'an and the Hadith, the desire to behave well towards other human beings ${ }^{46}$. For example, the Qur'an says, "There is no reward for good but good" (QS.55:60). It is clarified in an article that Islam as a teaching does not

\footnotetext{
${ }^{45}$ Myriam Hunter-Henin, "Living Together in an Age of Religious Diversity: Lessons from Baby Loup and SAS," Oxford Journal of Law and Religion 4, no. 1 (February 1, 2015): 94-118, https://doi.org/10.1093/ojlr/rwu060.

${ }^{46}$ Mansoureh Ebrahimi and Kamaruzaman Yusoff, "Islamic Identity, Ethical Principles and Human Values," European Journal of Multidisciplinary Studies 6, no. 1 (2017): 325, https://doi.org/10.26417/ejms.v6i1.p325-336.
} 
distinguish moral principles in their life activities since activities in the relationship of life with other human beings are part of obedience to the creator ${ }^{47}$.

The recognition of plural existence becomes part of the information of revelation through the Qur'an that, in reality, man has been created by different nations, tribes to know each other (QS.49:13). Islam acknowledges that other entities seem to be different, that does not preclude them from conducting worship and even protect them ${ }^{48}$.

On the other hand, the teachings of Islam strongly respect the rights of minorities ${ }^{49}$. Minority Rights in the Qur'an and the prophet Muhammad SAW when leading the state of Medina in the form of a medina constitution are best dealt with by non-Muslims ${ }^{50}$, then it is not necessary to claim that Islam does not accept the rights of minorities.

In the early days of Indonesian independence, Islamic leaders showed their national commitment by omitting seven terms in the Jakarta Charter ${ }^{51}$. In the sense of anti-violence in the teachings of Islam, there is something absolute. The teachings of Islam love humanity, as we can find clearly in the vulgar language in the Qur'an. 'Whoever kills a man, not because he kills others, as if he had killed all mankind?' (QS., 5:32). In fact, the teachings of Islam present the loving actions of the unity of humanity in many interests of cooperation, compassion for helping refugees, and there is no religious basis to accuse Islam in the text of the Qur'an and the sunnah of justifying abuse ${ }^{52}$.

\footnotetext{
47 J. Mark Halstead, "Islamic Values: A Distinctive Framework for Moral Education?," Journal of Moral Education 36, no. 3 (2007): 283-96, https://doi.org/10.1080/03057240701643056.

48 Muhammad Hifdil Islam, "Tolerance Limitation in Facing Religious Diversity Based on the Teaching of Islam," Nazhruna: Jurnal Pendidikan Islam 3, no. 1 (2020): 1-13, https://doi.org/10.31538/nzh.v3i1.483.

49 Mashood a. Baderin, "Islamic Law and International Protection of Minority Rights in Context," Brill's Arab and Islamic Laws Series 7, no. June 2013 (2013): 309-45, https://doi.org/10.1163/9789004233362_016.

${ }^{50}$ Havis Aravik, "Hak Minoritas Dalam Konteks Islam," Mizan: Journal of Islamic Law 5, no. 1 (2018): 63-78, http://jurnalfai-uikabogor.org/index.php/mizan/article/view/195.

${ }^{51}$ Wakhid Sugiyarto, "Wahdah Islamiyah, Radikaliame Dan Komitmen Kebangsaan," Harmoni 2, no. April (2013): 86-100.

52 Mohammed Abu-Nimer, A Framework for Nonviolence and Peacebuilding in Islam, Journal of Law and Religion, vol. 15, 2000, https://doi.org/10.2307/1051519.
} 
Comprehensive perception of Islam is a means of compliance with the incorporation of Islamic teachings into a Muslim's activities ${ }^{53}$. Islamic law derived from the Qur'an and the Sunnah is always in line with the changing times and places since the Qur'an is revealed to all humanity and becomes grace to all nature, so it is fitting that the teachings in it can always be interpreted uniformly.

Pleasant conduct in the association of life is a typical value recognized in all social ties of society ${ }^{54}$. The Qur'an teaches explicitly the order of hospitality to do good. It says in verse, 'Do good to others as God has done good to you' (QS.28:77).

At the end of the discussion, it is necessary to understand moderation in practice from the perspective of building democracy through education. Education is a medium of seed values, including moral values, which become the provision of educated people as they return to the social life in which they came from. Training thus becomes a strategy for instilling a moderate attitude of life. Learning in an educational setting is a deliberate endeavour and is designed employing an educational curriculum. An excellent educational curriculum is not extreme right or extreme left, but a moderate curriculum design, particularly spiritual and religious material.

\section{E. Conclusion}

The conclusion of this study as the objective of the study is to simplify the mentioning of the factors that form a moderate concept of religion. There are nine factors found theoretically generating religious moderation which is subsequently reduced by factor analysis to three factors with new names, namely diversity, peace, and education. For researchers who are interested in this topic, therefore, the author recommends that the three names be made into possible factors that can be tested through correlation, regression, or structural models to have a better analysis of the theme of religious moderation with quantitative methods and different analytical techniques.

\footnotetext{
53 a. Rahman Ritonga, "Memahami Islam Secara Kaffah: Integrasi Ilmu Keagamaan Dengan Ilmu_Ilmu Umum," Islam Realitas: Journal of Islamic \& Social Studies 2, no. 2 (2016): 118, https://doi.org/10.30983/islam_realitas.v2i2.183.

54 Bilal Khan, Ayesha Farooq, and Zareen Hussain, "Human Resource Management: An Islamic Perspective," Asia-Pacific Journal of Business Administration 2, no. 1 (2010): 17-34, https://doi.org/10.1108/17574321011037558.
} 
This research was restricted to the theory's efforts to classify test factors to shape a new category of factors. This thing is a weakness of our study at once. However, the new variables created are fascinating, as they will make it easier to mention advanced analysis variables. Diversity, peace, and education include several definitions that shape a broad, deep and rich understanding of religious moderation's nature in a higher education context.

\section{REFERENCES}

Abdul, Moh, Kholiq Hasan, Kamila Adnani, and Moh Mahbub. "Kontruksi Pemikiran Keagamaan Tentang Nilai-Nilai Nasionalisme Pada Penceramah Di Masjid Agung Surakarta Dan Sukoharjo IAIN Surakarta." Alulum Iain Gorontalo 18, no. 2 (2018): 481-500. https://doi.org/https://doi.org/10.30603/au.v18i2.660.

Abu-Nimer, Mohammed. A Framework for Nonviolence and Peacebuilding in Islam. Journal of Law and Religion. Vol. 15, 2000. https://doi.org/10.2307/1051519.

Adams, Katharine S., Jeremy R. Tost, Mark a. Whatley, Meghan C. Brown, Brendan J. Dochney, Jessica M. Taylor, and Mary H. Neal. "Relationship of Christian Beliefs to Attitudes toward People with Mental Illness." American Journal of $\begin{array}{lllll}\text { Psychotherapy } 71, \quad \text { no. } & \text { 104-9. }\end{array}$ https://doi.org/10.1176/appi.psychotherapy.20180022.

Akhmadi, Agus. "Moderasi Beragama Dalam Keragaman Indonesia Religious Moderation in Indonesia' S Diversity." Jurnal Diklat Keagamaan 13, no. 2 (2008): 45-55.

Ali, Nuraliah. "Measuring Religious Moderation Among Muslim Students at Public Colleges in Kalimantan Facing Disruption Era." INFERENSI: Jurnal Penelitian Sosial Keagamaan 14, no. 1 (2020): 1-24. https://doi.org/10.18326/infsl3.v14i1.1-24.

Alim, Nur, Pairin Pairin, Muh. Ikhsan, Samrin Samrin, and Syamsuddin Syamsuddin. "Singularitas Agama: Identifikasi Aliran Dan Paham Radikal Di Kendari.” Al-Ulum 18, no. 2 (2018): 271-300. https://doi.org/10.30603/au.v18i2.487.

Aravik, Havis. "Hak Minoritas Dalam Konteks Islam.” Mizan: Journal of Islamic Law 5, no. 1 (2018): 63-78. http://jurnalfaiuikabogor.org/index.php/mizan/article/view/195.

Arifinsyah. "The Urgency of Religious Moderation in Preventing Radicalism in Indonesia." Esensia 21, no. 1 (2020): 91-108. https://doi.org/https://doi.org/10.14421/esensia.v21i1.2199. 
Ashadi. "Sinkretisme Dalam Arsitektur: Metodologi." Jurnal Arsitektur NALARs Vol.13 No., no. 8 Maret 2017 (2014): 23-30.

Azra, Azyumardi. “Kesalehan Dan Politik: Islam Indonesia.” Studia Islamika 25, no. 3 (2018): 639-50.

Baderin, Mashood a. "Islamic Law and International Protection of Minority Rights in Context." Brill's Arab and Islamic Laws Series 7, no. June 2013 (2013): 309-45. https://doi.org/10.1163/9789004233362_016.

Berry, Jeffrey M. Lobbying for the People: The Political Behavior of Public Interest Groups. Princeton University Press, 2015.

Brown, David, and Ian Douglas Wilson. "Ethnicized Violence in Indonesia: Where Criminals and Fanatics Meet." Nationalism and Ethnic Politics 13, no. 3 (August 16, 2007): 367-403. https://doi.org/10.1080/13537110701451579.

Connelly, Karen. "Undermining Cosmopolitanism - Cyber-Racism Narratives in Australia." Sites: A Journal of Social Anthropology and Cultural Studies 13, no. 1 (2016): 156. https://doi.org/10.11157/sites-vol13iss1id318.

Ebrahimi, Mansoureh, and Kamaruzaman Yusoff. "Islamic Identity, Ethical Principles and Human Values." European Journal of Multidisciplinary Studies 6, no. 1 (2017): 325. https://doi.org/10.26417/ejms.v6i1.p325-336.

Echavarria, Ricardo. "Democratic Freedom of Expression." Open Journal of Philosophy 03 (January 1, 2013): $380-90$. https://doi.org/10.4236/ojpp.2013.33058.

Ellison, Christopher G, and Marc a Musick. "Southern Intolerance: A Fundamentalist Effect?." Social Forces 72, no. 2 (December 1, 1993): 37998. https://doi.org/10.1093/sf/72.2.379.

Emirbayer, Mustafa, and Chad Alan Goldberg. "Pragmatism, Bourdieu, and Collective Emotions in Contentious Politics." Theory and Society 34, no. 5 (2005): 469-518. https://doi.org/10.1007/s11186-005-1619-x.

Halstead, J. Mark. "Islamic Values: A Distinctive Framework for Moral Education?" Journal of Moral Education 36, no. 3 (2007): 283-96. https://doi.org/10.1080/03057240701643056.

Harcourt, Mark, Gregor Gall, Nisha Novell, and Margaret Wilson. "Boosting Union Membership: Reconciling Liberal and Social Democratic Conceptions of Freedom of Association via a Union Default." Industrial Law Journal, September 10, 2020. https://doi.org/10.1093/indlaw/dwaa018.

Hashim, Che Noraini, and Hasan Langgulung. "Islamic Religious Curriculum in Muslim Countries: The Experiences of Indonesia and Malaysia." Bulletin of Education \& Research 30, no. 1 (2008): 1-19.

Hunter-Henin, Myriam. "Living Together in an Age of Religious Diversity: Lessons from Baby Loup and SAS." Oxford Journal of Law and Religion 4, no. 1 (February 1, 2015): 94-118. https://doi.org/10.1093/ojlr/rwu060. 
Islam, Muhammad Hifdil. "Tolerance Limitation in Facing Religious Diversity Based on the Teaching of Islam." Nazhruna: Jurnal Pendidikan Islam 3, no. 1 (2020): 1-13. https://doi.org/10.31538/nzh.v3i1.483.

Islam, Tazul, and Amina Khatun. "Islamic Moderation' in Perspectives: A Comparison Between Oriental and Occidental Scholarships." International Journal of Nusantara Islam 3, no. 2 (2015): 69. https://doi.org/10.15575/ijni.v3i2.488.

Kasturirangan, Aarati, Sandhya Krishnan, and Stephanie Riger. "The Impact of Culture and Minority Status on Women's Experience of Domestic Violence." Trauma, Violence, \& Abuse 5, no. 4 (2004): 318-32. https://doi.org/10.1177/1524838004269487.

Khairil, Muhammad. “Wahdah Islamiyah's Counter-Radicalism Strategy Through the New Media Network in Da'wah Development of Palu City." Al-Ulum 18, no. 2 (2018): 417-35. https://doi.org/10.30603/au.v18i2.610.

Khan, Bilal, Ayesha Farooq, and Zareen Hussain. "Human Resource Management: An Islamic Perspective." Asia-Pacific Journal of Business Administration 2, no. 1 (2010): 17-34. https://doi.org/10.1108/17574321011037558.

Kharlie, Ahmad Tholabi, and M Ridwan Kubis. "The Portrait of Policy on Religious Harmony after the Post Reformation in Indonesia." International Journal of Psychosocial Rehabilitation, 24, no. 05 (2020): 2213-27. http://repository.uinjkt.ac.id/dspace/bitstream/123456789/50835/1/Arti kel.pdf.

Koyuncu, Ayşe Gözde, and Rufaro Denise Chipindu. "How Cultural Differences Influence Conflict Within an Organization: A Case Study of Near East University." International Journal of Organizational Leadership 8, no. 1 (2020): 112-28. https://doi.org/10.33844/ijol.2020.60478.

Lefevere, André. Translation, Rewriting, and the Manipulation of Literary Fame. Taylor \& Francis, 2016.

Lipman, Matthew. "Education for Democracy and Freedom." Wesleyan Graduate Review 1, no. 1 (1997): 32-38.

Lukoff, David, Francis G Lu, and Robert Turner. "Cultural Considerations in the Assessment and Treatment of Religious and Spiritual Problems." Psychiatric Clinics of North America 18, no. 3 (1995): 467-85. https://doi.org/https://doi.org/10.1016/S0193-953X(18)30035-2.

Murtadlo, Muhamad. "Menakar Moderasi Beragama Di Perguruan Tinggi." Badan Litbang Dan Diklat Kementerian Agama RI, 2019. https://balitbangdiklat.kemenag.go.id/berita/menakar-moderasiberagama-di-perguruan-tinggi.

Mustari Bosra. "Theological Moderation In The Islamic Boarding School (Pesantren): Phenomenological Prophetic Social Study In Pesantren In East Java." Akademika 25, no. 1 (2020): 118-38. https://doi.org/DOI: https://doi.org/10.32332/akademika.v25i1.2369. 
Nurdin, Ali. "Model Moderasi Beragama Berbasis Pesantren Salaf." Islamica Jurnal Studi Keislaman 14, no. 1 (2019): 1-21. https://doi.org/https://doi.org/10.15642/islamica.2019.14.1.82-102.

østby, Gudrun. "Polarization, Horizontal Inequalities and Violent Civil Conflict." Journal of Peace Research - J PEACE RES 45 (March 1, 2008): 143-62. https://doi.org/10.1177/0022343307087169.

Penyusun, Tim. Moderasi Beragama. Kementerian Agama. Vol. 53, 2013.

Ramanathan, Suresh, and Geetha Menon. "Time-Varying Effects of Chronic Hedonic Goals on Impulsive Behavior." Journal of Marketing Research 43 (September 1, 2006). https://doi.org/10.2139/ssrn.778944.

Ritonga, a. Rahman. "Memahami Islam Secara Kaffah: Integrasi Ilmu Keagamaan Dengan Ilmu_Ilmu Umum." Islam Realitas: Journal of Islamic \& Social $\begin{array}{lllll}\text { Studies } & 2, & \text { no. } & 2 & \text { (2016): }\end{array}$ https://doi.org/10.30983/islam_realitas.v2i2.183.

Sachdev, Itesh, and Richard Y. Bourhis. "Power and Status Differentials in Minority and Majority Group Relations." European Journal of Social Psychology 21, no. 1 (1991): 1-24. https://doi.org/10.1002/ejsp.2420210102.

Saifuddin, Ahmad. Psikologi Agama: Implementasi Psikologi Untuk Memahami Perilaku Agama. Kencana, 2019.

Salea, Falentino Y. "Tindak Pidana Mengganggu Ketenangan Sebagai Tindak Pidana Terhadap Ketertiban Umum Dalam Pasal 172 Dan Pasal 503 KUHP." Lex Crimen 9, no. 4 (2020).

Santoso, Singgih. Statistik Multivariat. Elex Media Komputindo, 2010.

Sugiyarto, Wakhid. "Wahdah Islamiyah, Radikaliame Dan Komitmen Kebangsaan." Harmoni 2, no. April (2013): 86-100.

Sutrisno, Edy. "Aktualisasi Moderasi Beragama Di Lembaga Pendidikan." Jurnal

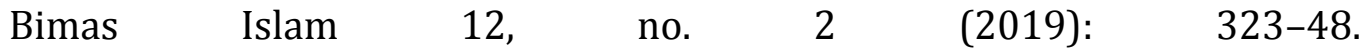
https://doi.org/10.37302/jbi.v12i2.113.

Tinarso, Pratisto, Supartiningsih Supartiningsih, and Hardono Hadi. "Aksiologi Nilai Egaliter Budaya 'Arek Suroboyo'.” Al-Ulum 18, no. 2 (2018): 395-416. https://doi.org/10.30603/au.v18i2.554.

Ushama, Thameem. "Is Islam a Religion of Moderation or Extremism? A Study of Key Islamic Teachings.” Asian Social Science 10, no. 8 (2014): 184-97. https://doi.org/10.5539/ass.v10n8p184.

Vertovec, Steven. "Super-Diversity and Its Implications." Ethnic and Racial Studies 30, no. 6 (2007): 1024-54.

Wibisono, Susilo, Winnifred R. Louis, and Jolanda Jetten. "A Multidimensional Analysis of Religious Extremism." Frontiers in Psychology 10, no. November (2019). https://doi.org/10.3389/fpsyg.2019.02560. 